\title{
利用扩环反应策略向稠环芳烃引入八元环
}

\author{
潘世豪缪 谦* \\ (香港中文大学化学系 香港)
}

\begin{abstract}
摘要 报道一种新合成策略, 通过扩环反应向稠环芳香骨架引入八元环. 利用这一策略, 成功合成了嵌入八元环的六 苯并冠. 单晶 X 射线衍射显示, 该分子的共轭骨架形如马鞍.
\end{abstract}

关键词 八元环; 稠环芳烃; 扩环反应

\section{Introduction of Eight-Membered Rings to Polycyclic Arenes by Ring Expansion}

\author{
Pun, Sai Ho Miao, Qian* \\ (Department of Chemistry, the Chinese University of Hong Kong, Hong Kong)
}

\begin{abstract}
A synthetic strategy based on a ring expansion reaction to introduce eight-membered rings into polycyclic aromatic frameworks is reported. The octagon-embedded hexabenzocoronene synthesized with this strategy features a saddle-shaped polycyclic framework as revealed by the single crystal X-ray crystallography.

Keywords eight-membered ring; polycyclic arenes; ring expansion
\end{abstract}

\section{Introduction}

Understanding how the topological defects define the geometries and properties of curved nanocarbons is of great importance in the research of carbon nanoscience. ${ }^{[1]}$ One common topological defect that cause the polycyclic framework to contort is non-hexagonal rings. Embedding four ${ }^{[2]}$ or five-membered rings ${ }^{[3]}$ into an otherwise planar polycyclic arene leads to positive curvature, which is the topological charater of aromatic bowls; while embedding seven ${ }^{[4-6]}$ or eight-membered rings ${ }^{[7]}$ into an otherwise planar polycyclic arene leads to negative curvature, which is the topological charater of aromatic saddles. Negatively curved polycyclic arenes (also known as aromatic saddles) represent fragments in carbon Schwarzites (also known as Mackay crystals) ${ }^{[8]}$ which are theoretical negatively curved carbon allotropes of aesthetic structures and interesting properties but have not been synthesized unambiguously yet. ${ }^{[9-10]}$ Negatively curved polycyclic arenes contain structual infromation of carbon Schwarzites and can in principle be used as building blocks in a bottom-up approch to the synthesis of carbon Schwarzites. Moreover, negatively curved polycyclic arenes present unique stere- ochemistry and properties that are not available to planar or positively curved polycycylic arenes. For these reasons, negatively curved polycyclic arenes have recently received more and more attentions. ${ }^{[1]}$

Difficulty in the synthesis of negatively curved polycyclic arenes is mainly associated with their considerable strain, which is more significant in polycyclic arenes containing eight-membered rings. ${ }^{[12]}$ So far, only a handful of methods are availabe for constructing eight-membered rings in polycyclic arenes. ${ }^{[7,13]}$ Moreover, already-formed eight-membered rings may suffer skeletal rearrangement during the oxidative cyclodehydrogenation reaction, ${ }^{[14]}$ which predominates in the synthesis of large polycyclic arenes. As a result, new synthetic strategies need to be explored for introduction of eight-membered rings into polycyclic arenes. Recently, our group successfully utilized a ring expansion strategy to construct the seven-membered rings in negatively curved polycyclic arenes as shown in Scheme $1 \mathrm{a} .{ }^{[6]}$ Herein, we demonstate that this strategy can be extended for introduction of an eight-membered ring into polycyclic aromatic frameworks as shown in Scheme $1 \mathrm{~b}$.

\footnotetext{
* Corresponding author. E-mail: miaoqian@cuhk.edu.hk

Received May 14, 2020; revised June 26, 2020; published online July 15, 2020.

Dedicated to Professor Henry N. C. Wong on the occasion of his 70th birthday.

Project supported by the Research Grants Council of Hong Kong (No. GRF 14300919)

香港研究资助局优配研究金(No. GRF14300919)资助项目.
} 
(a) Previous work

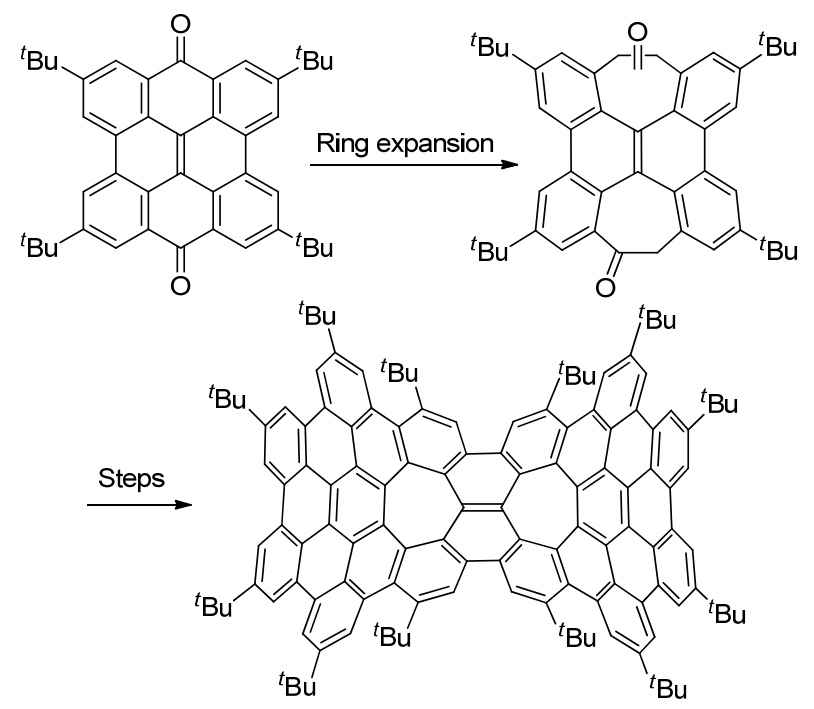

(b) This work

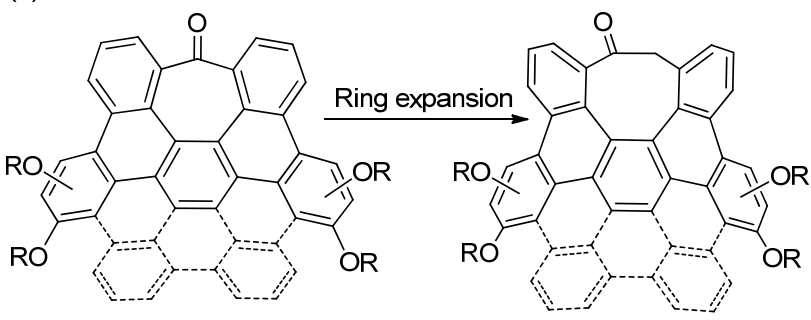

Scheme 1 (a) Reported introduction of seven-membered rings into polycyclic arenes by ring expansion, and (b) introduction of an eight-membered ring to polycyclic arenes by ring expansion

\section{Results and discussion}

The ring expansion strategy in the synthesis of two polycyclic arenes containing an eight-membered ring, namely 4 (Scheme 2) and 9 (Scheme 3) was tested. As shown in Scheme 2, the synthesis of 4 started with 2,3:6,7-dibenzocycloheptadiene-1,4,5-trione, which can be easily obtained by a one-step oxidation of commercially available 5-dibenzosuberenone ${ }^{[15]}$. Double Aldol condensation of the trione with 1,3-bis(3,4-dimethoxyphenyl)-2-propanone ${ }^{[16]}$ afforded cyclopentadiene-one $\mathbf{1}$ in a yield of $68 \%$. Diels-Alder reaction of $\mathbf{1}$ and norbornadiene, followed by retro-Diels-Alder reaction afforded $\mathbf{2 a}$ in a yield of $83 \%$. After the methyl groups in $\mathbf{2 a}$ were replaced by longer hexyl chains to provide sufficient solubility, the Scholl reaction $^{[17-18]}$ of $\mathbf{2 b}$ with 2,3-dichloro-5,6-dicyano-1,4-benzoquinone (DDQ) and triflic acid $(\mathrm{TfOH})^{[19]}$ resulted 3 with the formation of two carbon-carbon bonds in a moderate yield. Here, the oxidative cyclodehydrogenation is facilitated by the alkoxyl groups that are positioned meta and para to the reaction site. ${ }^{[20]}$ Treatment of $\mathbf{3}$ with trimethylsilyldiazomethane $\left(\mathrm{TMSCHN}_{2}\right)^{[21-22]}$ at the presence of boron trifluoride etherate enabled ring expansion and thus afforded 4 in a yield of $80 \%$.

Scheme 3 shows the synthesis of $\mathbf{9}$, an octagon embedded hexabenzocoronene (HBC) from $\mathbf{5}$, which, similar to $\mathbf{1}$,
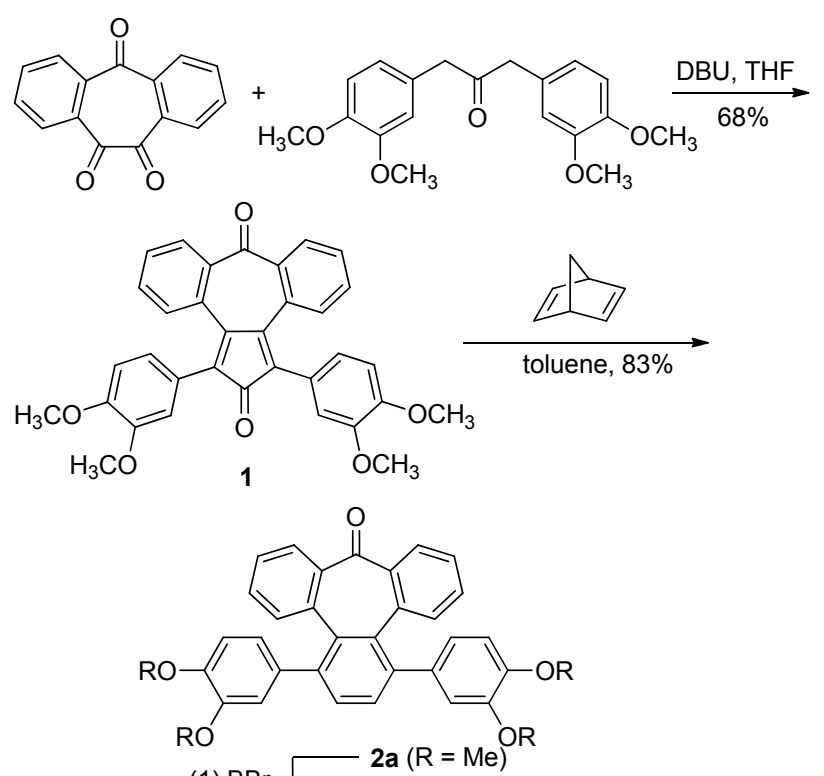

(2) $\mathrm{K}_{2} \mathrm{CO}_{3}, \mathrm{C}_{6} \mathrm{H}_{13} \mathrm{Br} 84 \%$
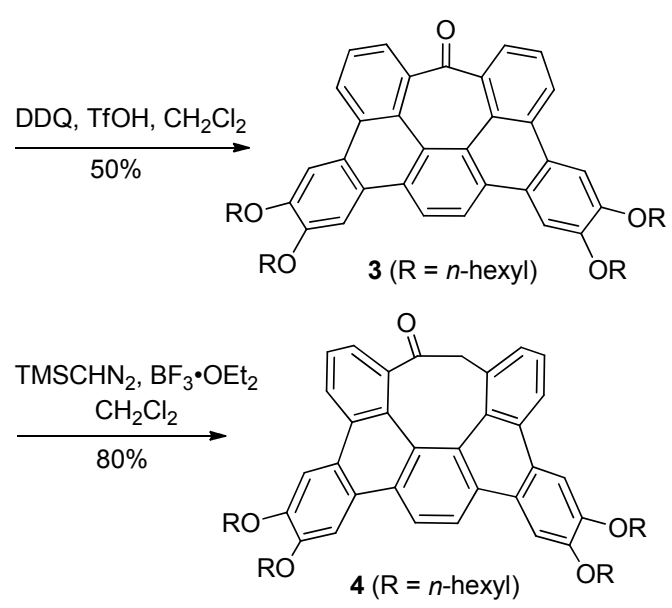

Scheme 2 Synthesis of 4

was prepared from 2,3:6,7-dibenzocycloheptadiene-1,4,5trione following the reported procedure. ${ }^{[15]}$ Diels-Alder reaction of 5 with diphenyl acetylene followed by decarbonylation gave hexaphenylbenzene derivative 6a. After the methyl groups in $\mathbf{6 a}$ were replaced by longer hexyl chains to increase solubility, the Scholl reaction of $\mathbf{6 b}$ with DDQ and $\mathrm{TfOH}$ led to 7 with the formation of five carbon-carbon bonds in a yield of 53\%. The four alkoxy groups in $\mathbf{6 b}$ are important to activate the desired positions for oxidative cyclodehydrogenation ${ }^{[23]}$ as noted earlier with the synthesis of the heptagon-embedded HBC. ${ }^{[4]}$ Treatment of 7 with $\mathrm{TMSCHN}_{2}$ at the presence of boron trifluoride etherate enabled ring expansion and thus afforded $\mathbf{8}$ in a yield of $80 \%$. This indicates that the ring expansion strategy is applicable to curved and extended $\pi$-backbones. Decarbonylation of 8 by $\mathrm{LiAlH}_{4} / \mathrm{AlCl}_{3}$ led to 9 in a yield of $72 \%$. Attempted dehydrogenation of 9 with a variety of reagents, such as DDQ or $\mathrm{Pd} / \mathrm{C}$ for direct dehydrogenation, and bromination followed by elimination, all failed to yield $\mathbf{1 0}$ presumably 
<smiles>COc1cc(OC)cc(C2=C(c3cc(OC)cc(OC)c3)C(c3ccccc3C(=O)c3ccccc3)=C(c3cc(OC)cc(OC)c3)C2=O)c1</smiles>

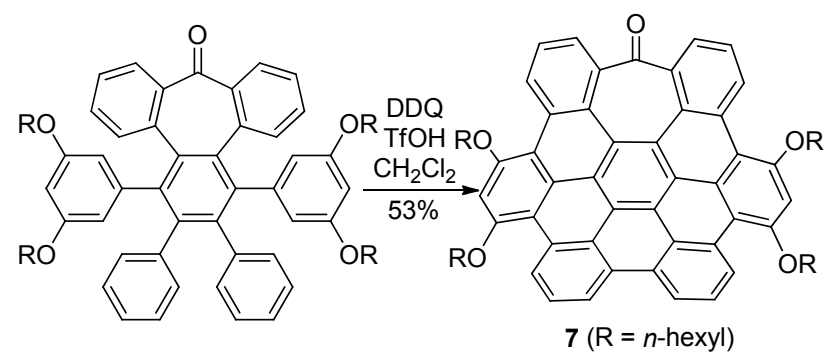

$$
\begin{aligned}
& \text { (1) } \mathrm{BBr}_{3} \quad \mathbf{6 a}(\mathrm{R}=\mathrm{Me}) \\
& \text { (2) } \mathrm{K}_{2} \mathrm{CO}_{3} \\
& \mathrm{C}_{6} \mathrm{H}_{13} \mathrm{Br} \longrightarrow \mathbf{6 b}(\mathrm{R}=n \text {-hexyl) }
\end{aligned}
$$
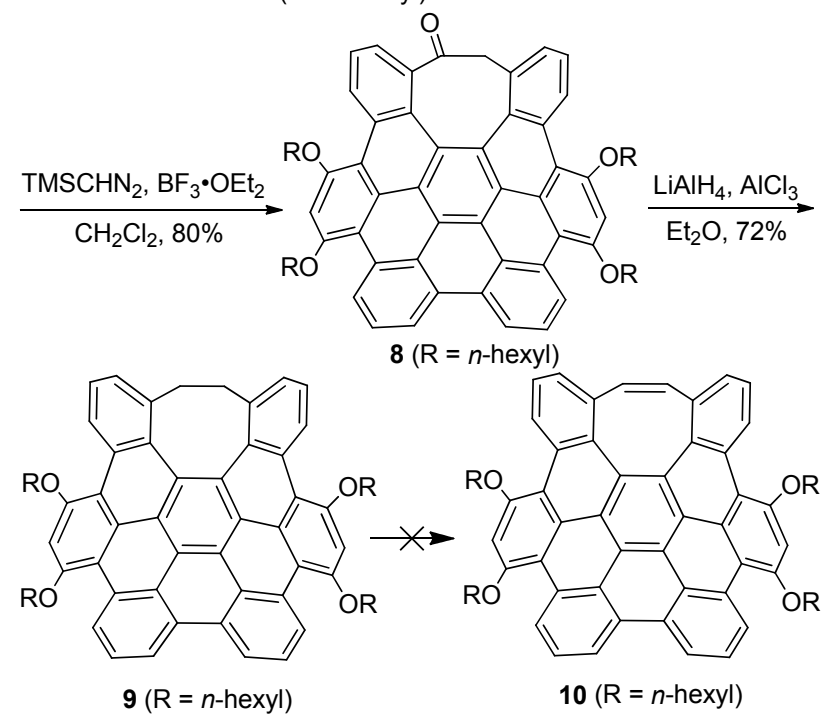

Scheme 3 Synthesis of 9

because the reactivity of four benzylic methylene groups is changed by the contorted eight-membered ring.

Single crystals of 9 suitable for X-ray crystallography were obtained from solutions in dichloromethane and ethyl acetate by slow evaporation of solvents. ${ }^{[24]}$ In the single crystals, 9 exists as a pair of enantiomers, which have helical chirality due to the embedded [5] helicene subunit. However, this chiral structure can be racemized through the eight-membered ring flipping as suggested by the broad peaks at $\delta 3.10 \sim 3.24$ in ${ }^{1} \mathrm{H}$ NMR at room temperature for the methylene groups in the eight-membered ring. As shown in Figure 1a, the $\pi$-backbone of 9 (even with two $\mathrm{sp}^{3}$ carbon atoms in the eight-membered ring excluded) is curved like a saddle and thus presents negative curvature. As shown in Figure $1 \mathrm{~b}$, the $\mathrm{C}-\mathrm{C}$ bonds shown in magenta, which exhibit bond lengths of $0.147 \sim 0.149 \mathrm{~nm}$, are significantly longer than a typical $\mathrm{C}-\mathrm{C}$ aromatic bond $(0.138 \sim 0.140 \mathrm{~nm})$ but resemble $\mathrm{C}-\mathrm{C}$ single bonds between $\mathrm{sp}^{2}$-sp $^{2}$ carbons, which have a typical bond length of
$0.145 \sim 0.148 \mathrm{~nm} .{ }^{[25]}$ As shown in Figure 1c, molecules of 9 stack with $\pi-\pi$ interactions, which exhibit two different $\pi$-to- $\pi$ distances between neighboring molecules. The $\pi$-to- $\pi$ distance of $0.348 \mathrm{~nm}$ is associated with overlap of roughly three benzenoid rings, while the $\pi$-to- $\pi$ distance of $0.357 \mathrm{~nm}$ is associated with overlap of roughly one benzenoid ring.

(a)

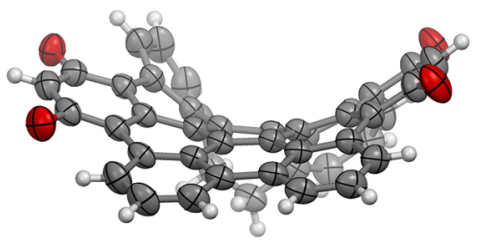

(b)
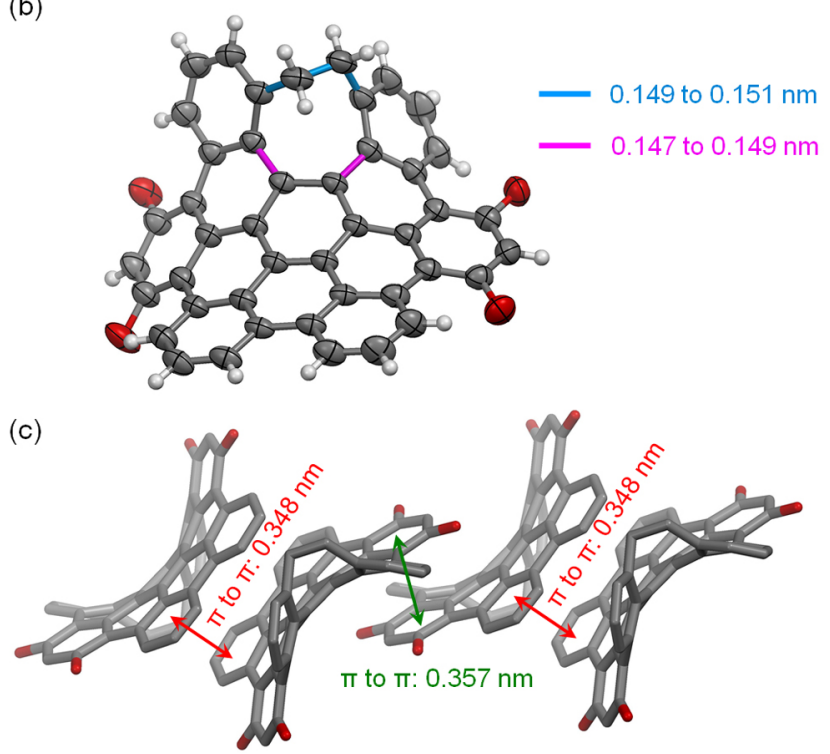

Figure 1 Crystal structure of 9

(a) Side view showing the saddle-like shape; (b) top view with $\mathrm{C}-\mathrm{C}$ single bonds in the eight-membered ring highlighted; (c) molecular packing with $\pi-\pi$ stacking. Hexyl groups removed for clarity. Carbon and oxygen atoms in (a) and (b) are shown as grey and red ellipsoids, respectively, at $50 \%$ probability level

Compound 9 is soluble in common organic solvents resulting in yellow solutions and appears green fluorescence upon excited with UV light. As shown in Figure 2a, the UV-vis absorption of 9 exhibits an intense peak at $363 \mathrm{~nm}$ and weak absorption band at $472 \mathrm{~nm}$. The fluorescent spectrum of 9 exhibits a small Stoke shift of $10 \mathrm{~nm}$, which suggests that the polycyclic aromatic backbone of $\mathbf{9}$ is as rigid as that of the earlier reported heptagon-embedded HBC. ${ }^{[4]}$ As estimated from the absorption edge, the HOMO-LUMO gap of 9 is $2.58 \mathrm{eV}$. As shown in Figure 2b, the cyclic voltammogram of 9 in $\mathrm{CH}_{2} \mathrm{Cl}_{2}$ exhibits two reversible oxidation waves with a half-wave oxidation potential of 0.38 and $0.62 \mathrm{~V}$ vs. ferrocenium/ferrocene $\left(\mathrm{F}_{\mathrm{c}}^{+} / \mathrm{F}_{\mathrm{c}}\right)$, respectively. From the half-wave oxidation, the HOMO energy level of 9 is estimated as $-5.48 \mathrm{eV} .^{[26]}$

\section{Conclusions}

In summary, the successful syntheses of $\mathbf{4}$ and $\mathbf{9}$ indicate 


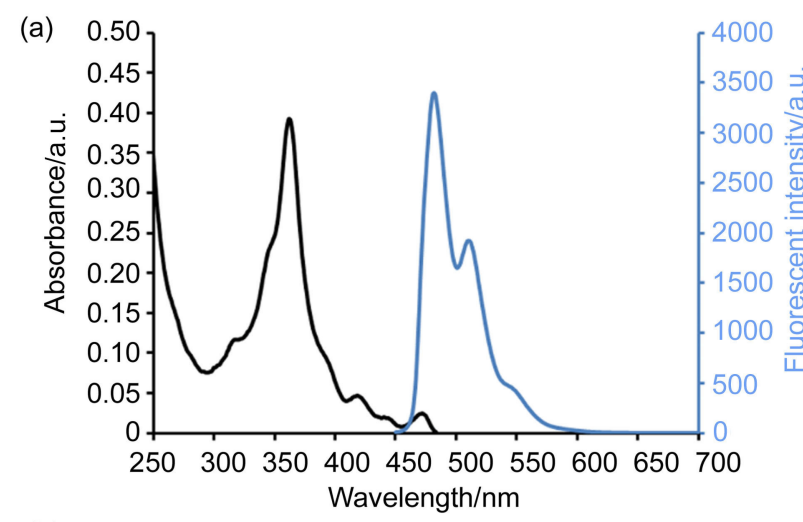

(b)

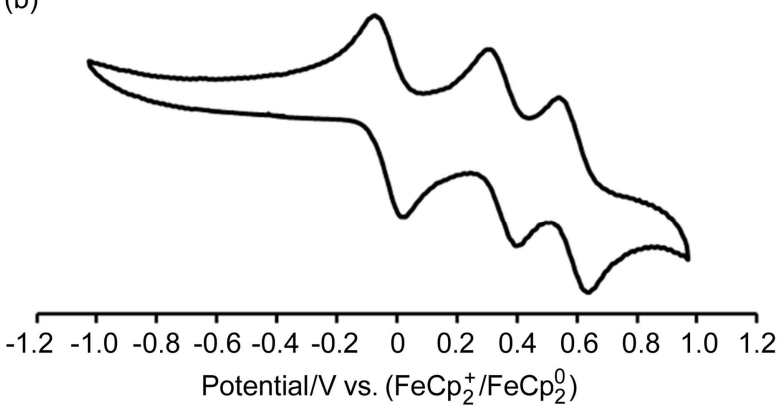

Figure 2 (a) UV-vis absorption (black line) and fluorescence (blue line) were recorded with excitation at $472 \mathrm{~nm}$ ) spectra of 9 in solution $\left(1 \times 10^{-5} \mathrm{~mol} / \mathrm{L}\right.$ in $\left.\mathrm{CH}_{2} \mathrm{Cl}_{2}\right)$; (b) cyclic voltammogram of 9

that the ring expansion is a useful strategy to introduce eight-membered rings into polycyclic aromatic frameworks. The single crystal X-ray crystallography reveals that 9 has a negatively curved $\pi$-backbone, which is $\pi$-isoelectronic to hexabenzocoronene (HBC), an wellknown planar polycyclic arene. ${ }^{[27]}$ The study on the electronic structure of $\mathbf{4}$ sheds light on the effect of an eight-mem- bered ring defect on a planar polycyclic aromatic system. This ring expansion strategy opens a new avenue to synthesis of negatively curved polycyclic arenes. Further study on the $\pi$-expansion of $\mathbf{4}$ is in progress in our laboratory.

\section{Experimental section}

\subsection{General}

The reagents and starting materials employed were commercially available and used without any further purification or made following reported methods as indicated. Unless otherwise noted, all reactions were performed with dry solvents under an atmosphere of nitrogen in dried glassware with standard vacuum-line techniques. Anhydrous and oxygen-free dichloromethane, tetrahydrofuran, and toluene were purified by an Advanced Technology Pure-Solv PS-MD-4 system. NMR spectra were recorded on a Brucker ADVANCE III $400 \mathrm{MHz}$ spectrometer $\left({ }^{1} \mathrm{H}\right.$ NMR: $400 \mathrm{MHz},{ }^{13} \mathrm{C}$ NMR: $100 \mathrm{MHz}$ ). Chemical shift values $(\delta)$ were expressed using residual solvent protons $\left({ }^{1} \mathrm{H}\right.$ $\mathrm{NMR}, \delta_{\mathrm{H}}=7.26$ for $\mathrm{CDCl}_{3} ;{ }^{13} \mathrm{C} \mathrm{NMR}, \delta_{\mathrm{C}}=77.16$ for $\mathrm{CDCl}_{3}$ ) as internal standard. Mass spectra were recorded on a Bruker Autoflex speed MALDI-TOF spectrometer. X-ray crystallography data were collected on a Bruker AXS Kappa ApexII Duo Diffractometer. UV-vis absorption spectra were recorded on a Varian CARY 1E UV-vis spectrophotometer. Fluorescence spectra were taken on a Hitachi F-4500 spectrofluorometer. Melting points, without correction, were measured using a Nikon Polarized Light Microscope ECLIPSE 50i POL equipped with an INTEC HCS302 heating stage. The cyclic voltammetry was performed in a solution of $\mathrm{CH}_{2} \mathrm{Cl}_{2}$ with $0.1 \mathrm{~mol} / \mathrm{L} \mathrm{Bu}_{4} \mathrm{NPF}_{6}$ as the supporting electrolyte, at a scan rate of $50 \mathrm{mV} \cdot \mathrm{s}^{-1}$. Ferrocene/ferrocenium was used as the internal standard. Potentials were referenced to ferrocenium/ferrocene $\left(\mathrm{Fc}^{+} /\right.$ $\mathrm{Fc})$.

\subsection{Synthesis}

1,3-Bis(3,4-dimethoxyphenyl)dibenzo[ $e, h]$ azulene-2,8dione (1): To a solution of 2,3:6,7-dibenzocycloheptadiene-1,4,5-trione $(2.70 \mathrm{~g}, 9.4 \mathrm{mmol})$ and 1,3-bis(3,4-dimethoxyphenyl)-2-propanone ( $3.12 \mathrm{~g}, 9.4 \mathrm{mmol}, 1$ equiv.) in $90 \mathrm{~mL}$ of anhydrous tetrahydrofuran (THF) was added 1,8-diazabicyclo(5.4.0)undec-7-ene (DBU) (0.7 mL, 4.7 mmol, 0.5 equiv.). The reaction mixture was stirred at room temperature for $5 \mathrm{~h}$ and then quenched with $1 \mathrm{~mol} / \mathrm{L} \mathrm{HCl}$ aqueous solution. The resulting mixture was extracted with $\mathrm{CH}_{2} \mathrm{Cl}_{2}$. The organic layer was washed with brine, dried with anhydrous $\mathrm{MgSO}_{4}$ and concentrated under reduced pressure. The crude mixture was triturated with cold methanol/diethyl ether $(V: V=20: 1)$ and dried under vacuum to afford $3.40 \mathrm{~g}(6.4 \mathrm{mmol})$ of 1 as a dark green solid in a yield of $68 \%$. m.p. $214 \sim 216{ }^{\circ} \mathrm{C} ;{ }^{1} \mathrm{H}$ NMR $\left(\mathrm{CDCl}_{3}\right) \delta: 7.62(\mathrm{~d}, J=7.6 \mathrm{~Hz}, 2 \mathrm{H}), 7.39 \sim 7.25(\mathrm{~m}, 6 \mathrm{H})$, $6.89 \sim 6.81(\mathrm{~m}, 4 \mathrm{H}), 6.61(\mathrm{~d}, J=1.6 \mathrm{~Hz}, 2 \mathrm{H}), 3.89(\mathrm{~s}, 6 \mathrm{H})$, $3.65(\mathrm{~s}, 6 \mathrm{H}) ;{ }^{13} \mathrm{C} \mathrm{NMR}\left(\mathrm{CDCl}_{3}\right) \delta: 200.9,199.8,149.8$, $149.2,148.7,141.5,131.8,131.5,130.2,130.1,128.3$, 126.7, 123.4, 123.0, 112.6, 111.2, 55.9, 55.7; HRMS (MALDI-TOF) calcd for $\mathrm{C}_{34} \mathrm{H}_{26} \mathrm{O}_{6}$ 530.1724, found 530.1724 .

1,4-Bis(3,4-dimethoxyphenyl)tribenzo[a,c,e]cycloheptatriene-9-one (2a): To a solution of $\mathbf{1}(2.71 \mathrm{~g}, 5.1 \mathrm{mmol})$ in $17 \mathrm{~mL}$ of toluene was added bicyclo[2.2.1]hepta-2,5-diene (1.0 mL, $9.8 \mathrm{mmol}, 1.9$ equiv.) under atmosphere of nitrogen. The reaction mixture was refluxed for $72 \mathrm{~h}$. The crude mixture was concentrated under reduced pressure and purified by column chromatography on silica gel with hexane/ $\mathrm{CH}_{2} \mathrm{Cl}_{2} /$ diethyl ether $(V: V: V=1: 1: 1)$ as eluent to afford $2.23 \mathrm{~g}(0.43 \mathrm{mmol})$ of $\mathbf{2} \mathbf{a}$ as a white solid in a yield of 83\%. m.p. 282 $287{ }^{\circ} \mathrm{C} ;{ }^{1} \mathrm{H}$ NMR $\left(\mathrm{CDCl}_{3}\right) \delta$ : $7.54(\mathrm{~s}, 2 \mathrm{H})$, $7.51,(\mathrm{~d}, J=7.6 \mathrm{~Hz}, 2 \mathrm{H}), 7.23 \sim 7.19(\mathrm{~m}, 2 \mathrm{H}), 7.00 \sim 6.97$ $(\mathrm{m}, 4 \mathrm{H}), 6.81$ (br s, 4H), 6.25 (br s, 2H), 3.88 (s, 6H), 3.53 $(\mathrm{s}, 6 \mathrm{H}) ;{ }^{13} \mathrm{C} \mathrm{NMR}\left(\mathrm{CDCl}_{3}\right) \delta: 199.7,148.3,147.9,145.9$, $141.6,135.6,135.0,134.6,133.7,131.3,129.5,127.6$, $124.9,121.8,113.2,111.0,55.9,55.7$; HRMS (MALDITOF) calcd for $\mathrm{C}_{35} \mathrm{H}_{28} \mathrm{O}_{5} 528.1931$, found 528.1939.

1,4-Bis(3,4-dihexoxyphenyl)tribenzo[a,c,e]cycloheptatriene-9-one (2b): To a suspension of 2a (164 mg, 0.31 $\mathrm{mmol}$ ) in $20 \mathrm{~mL}$ of anhydrous $\mathrm{CH}_{2} \mathrm{Cl}_{2}$ was added solution 
of $\mathrm{BBr}_{3}$ (5.0 mL, $1 \mathrm{~mol} / \mathrm{L}$ in $\mathrm{CH}_{2} \mathrm{Cl}_{2}, 5.0 \mathrm{mmol}, 16$ equiv.) at $0{ }^{\circ} \mathrm{C}$ under atmosphere of nitrogen. The reaction mixture was warmed to room temperature and heated to reflux for 4 $\mathrm{h}$, and then was cooled with ice bath and quenched with $\mathrm{H}_{2} \mathrm{O}$. The mixture was extracted with diethyl ether, washed with water and brine, dried with anhydrous $\mathrm{MgSO}_{4}$, and concentrated under reduced pressure. The resulting tetraol was used in the next step without further purification.

To a suspension of the crude tetraol and $\mathrm{K}_{2} \mathrm{CO}_{3}(858 \mathrm{mg}$, $6.2 \mathrm{mmol}, 20$ equiv.) in $3 \mathrm{~mL}$ of $N, N$-dimethylformamide (DMF) was added 1-bromohexane $(0.67 \mathrm{~mL}, 6.2 \mathrm{mmol}, 20$ equiv.) under atmosphere of nitrogen. The reaction mixture was heated at $80{ }^{\circ} \mathrm{C}$ overnight, cooled to room temperature, and then quenched with water. The resulting mixture was extracted with diethyl ether, washed with water and brine, dried with anhydrous $\mathrm{MgSO}_{4}$. The resulting solution was concentrated under reduced pressure and the crude product was purified by column chromatography on silica gel with hexane/ $\mathrm{CH}_{2} \mathrm{Cl}_{2}(V: V=1: 1 \sim 1: 2)$ as eluent to afford $213 \mathrm{mg}(0.26 \mathrm{mmol})$ of $\mathbf{2 b}$ as pale-yellow oil in a yield of 84\%. ${ }^{1} \mathrm{H}$ NMR $\left(\mathrm{CDCl}_{3}\right) \delta: 7.52(\mathrm{~s}, 2 \mathrm{H}), 7.50(\mathrm{~d}, J=7.2 \mathrm{~Hz}$, $2 \mathrm{H}), 7.20(\mathrm{t}, J=8.0 \mathrm{~Hz}, 2 \mathrm{H}), 7.02 \sim 6.94(\mathrm{~m}, 4 \mathrm{H}), 6.78(\mathrm{br} \mathrm{s}$, $6 \mathrm{H}), 4.02 \sim 3.93(\mathrm{~m}, 4 \mathrm{H}), 3.73 \sim 3.47(\mathrm{~m}, 4 \mathrm{H}), 1.84 \sim 1.71$ $(\mathrm{m}, 8 \mathrm{H}) 1.48 \sim 1.35(\mathrm{~m}, 24 \mathrm{H}), 0.95 \sim 0.90(\mathrm{~m}, 12 \mathrm{H}) ;{ }^{13} \mathrm{C}$ NMR $\left(\mathrm{CDCl}_{3}\right) \delta: 199.7,148.6,147.9,145.8,141.7,135.5$, $135.2,134.6,133.7,131.2,129.3,127.4,124.8,121.9$, 115.4, 113.5, 31.7, 31.6, 29.3, 29.1, 25.7, 25.8, 22.7, 22.7, 14.1, 14.1; HRMS (MALDI-TOF) calcd for $\mathrm{C}_{55} \mathrm{H}_{68} \mathrm{O}_{5}$ 808.5061, found 808.5053.

3: To a solution of $\mathbf{2 b}(213 \mathrm{mg}, 0.26 \mathrm{mmol})$ and 2,3-dichloro-5,6-dicyanobenzoquinone $(131 \mathrm{mg}, \quad 0.58$ mmol, 2.2 equiv.) in $80 \mathrm{~mL}$ of anhydrous $\mathrm{CH}_{2} \mathrm{Cl}_{2}$ was added trifluoromethanesulfonic acid $(1.4 \mathrm{~mL}, 15.8 \mathrm{mmol}, 61$ equiv.) under atmosphere of nitrogen. The reaction mixture was kept stirred at $0{ }^{\circ} \mathrm{C}$ for $30 \mathrm{~min}$ and then quenched with $10 \% \mathrm{NaHCO}_{3}$ aqueous solution. The resulting mixture was extracted with $\mathrm{CH}_{2} \mathrm{Cl}_{2}$. The organic layer was washed with brine, dried with anhydrous $\mathrm{MgSO}_{4}$ and concentrated under reduced pressure. The crude product was purified by column chromatography on silica gel with hexane $/ \mathrm{CH}_{2} \mathrm{Cl}_{2}$ $(V: V=1: 1 \sim 1: 2)$ as eluent to afford $104 \mathrm{mg}(0.13$ mmol) of 3 as a pale-yellow solid in a yield of $50 \%$. m.p. $145 \sim 147{ }^{\circ} \mathrm{C} ;{ }^{1} \mathrm{H}$ NMR $\left(\mathrm{CDCl}_{3}\right) \delta: 8.64(\mathrm{~s}, 2 \mathrm{H}), 8.61(\mathrm{~d}$, $J=7.2 \mathrm{~Hz}, 2 \mathrm{H}), 7.87(\mathrm{~m}, 4 \mathrm{H}), 7.81(2 \mathrm{H}), 7.78(\mathrm{t}, J=8.0 \mathrm{~Hz}$, $2 \mathrm{H}), 4.23 \sim 4.19(\mathrm{~m}, 8 \mathrm{H}), 1.98 \sim 1.93(\mathrm{~m}, 8 \mathrm{H}), 1.61 \sim 1.57$ $(\mathrm{m}, 8 \mathrm{H}), 1.45 \sim 1.40(\mathrm{~m}, 16 \mathrm{H}), 0.98 \sim 0.92(\mathrm{~m}, 12 \mathrm{H}) ;{ }^{13} \mathrm{C}$ NMR $\left(\mathrm{CDCl}_{3}\right) \delta: 202.7,150.1,150.1,141.4,130.5,129.3$, $127.4,126.9,126.3,125.8,124.9,123.7,123.5,122.1$, 107.2, 106.0, 31.8, 29.4, 29.4, 25.9, 22.8, 22.8, 14.2, 14.2; HRMS (MALDI-TOF) calcd for $\mathrm{C}_{55} \mathrm{H}_{64} \mathrm{O}_{5} 804.4748$, found 804.4735.

4: To a solution of $3(55 \mathrm{mg}, 0.07 \mathrm{mmol})$ in $6 \mathrm{~mL}$ of anhydrous $\mathrm{CH}_{2} \mathrm{Cl}_{2}$ was added boron trifluoride diethyl etherate $(0.1 \mathrm{~mL}, 0.81 \mathrm{mmol}, 12$ equiv. $)$ at $0{ }^{\circ} \mathrm{C}$ under atmosphere of nitrogen. The reaction mixture was kept stirred at $0{ }^{\circ} \mathrm{C}$ for $10 \mathrm{~min}$. Then, a solution of (trimethylsilyl)diazomethane $(0.05 \mathrm{~mL}, 2.0 \mathrm{~mol} / \mathrm{L}$ in hexane, 0.1 mmol, 1.4 equiv.) was added into the mixture. The resulting mixture was kept stirred at $0{ }^{\circ} \mathrm{C}$ for $2.5 \mathrm{~h}$. The reaction mixture was quenched with water. The resulting mixture was extracted with $\mathrm{CH}_{2} \mathrm{Cl}_{2}$. The organic layer was washed with brine, dried with anhydrous $\mathrm{MgSO}_{4}$ and concentrated under reduced pressure. The crude product was purified by column chromatography on silica gel with hexane $/ \mathrm{CH}_{2} \mathrm{Cl}_{2}$ $(V: V=1: 2)$ as eluent to afford $46 \mathrm{mg}(0.056 \mathrm{mmol})$ of 4 as yellow solid in a yield of $80 \%$. m.p. $191 \sim 194{ }^{\circ} \mathrm{C} ;{ }^{1} \mathrm{H}$ $\operatorname{NMR}\left(\mathrm{CDCl}_{3}\right) \delta: 8.577 \sim 8.582(\mathrm{~m}, 2 \mathrm{H}), 8.39(\mathrm{~d}, J=7.2 \mathrm{~Hz}$, $1 \mathrm{H}), 8.29 \sim 8.27(\mathrm{~m}, 2 \mathrm{H}), 7.93(\mathrm{~s}, 1 \mathrm{H}), 7.78(\mathrm{~s}, 1 \mathrm{H}), 7.74(\mathrm{~s}$, $1 \mathrm{H}), 7.73(\mathrm{t}, J=7.6 \mathrm{~Hz}, 1 \mathrm{H}), 7.58 \sim 7.56(\mathrm{~m}, 2 \mathrm{H}), 7.42(\mathrm{t}$, $J=7.6 \mathrm{~Hz}, 1 \mathrm{H}), 4.60(\mathrm{~d}, J=10.8 \mathrm{~Hz}, 1 \mathrm{H}), 4.32 \sim 4.14(\mathrm{~m}$, $8 \mathrm{H}), 3.86(\mathrm{~d}, J=10.8 \mathrm{~Hz}, 1 \mathrm{H}), 2.00 \sim 1.86(\mathrm{~m}, 8 \mathrm{H}), 1.55 \sim$ $1.51(\mathrm{~m}, 8 \mathrm{H}), 1.40 \sim 1.37(\mathrm{~m}, 16 \mathrm{H}), 0.97 \sim 0.89(\mathrm{~m}, 12 \mathrm{H})$; ${ }^{13} \mathrm{C}$ NMR $\left(\mathrm{CDCl}_{3}\right) \delta: 194.4,150.5,150.0,150.0,149.9$, $136.0,135.1,132.2,132.0,131.5,130.3,129.9,129.8$, $128.5,128.1,127.8,127.1,125.7,125.4,125.2,124.9$, $124.7,124.6,124.5,122.7,122.2,121.3,107.5,107.3$, $106.5,106.2,69.6,69.5,69.3,47.7,31,8,31.7,29.4,29.3$, 29.3, 25.9, 25.8, 22.8, 22.7, 14.2, 14.2; HRMS (MALDITOF) calcd for $\mathrm{C}_{56} \mathrm{H}_{66} \mathrm{O}_{5} 818.4905$, found 818.4913.

1,4-Bis(3,5-dimethoxyphenyl)-2,3-diphenyl-tribenzo$[a, c, e]$ cycloheptatriene-9-one (6a): To a solution of 5 (3.0 $\mathrm{g}, 5.7 \mathrm{mmol})$ and diphenylacetylene $(1.02 \mathrm{~g}, 5.7 \mathrm{mmol}, 1$ equiv.) in $4 \mathrm{~mL}$ of diphenyl ether was refluxed for $16 \mathrm{~h}$ under atmosphere of nitrogen. The mixture was cooled to room temperature, filtered and triturated with cold methanol to afford $2.72 \mathrm{~g}(4.0 \mathrm{mmol})$ of $\mathbf{6 a}$ as beige solid in a yield of $70 \%$. m.p. not melt when heated to $300{ }^{\circ} \mathrm{C} .{ }^{1} \mathrm{H}$ NMR $\left(\mathrm{CDCl}_{3}\right) \delta: 7.44(\mathrm{~d}, J=7.6 \mathrm{~Hz}, 2 \mathrm{H}), 7.39$ (d, $J=7.6$ $\mathrm{Hz}, 2 \mathrm{H}), 7.17$ (t, $J=7.6 \mathrm{~Hz}, 2 \mathrm{H}), 7.11(\mathrm{~d}, J=8.0 \mathrm{~Hz}, 2 \mathrm{H})$, $7.06(\mathrm{t}, J=7.2 \mathrm{~Hz}, 2 \mathrm{H}), 6.95(\mathrm{t}, J=7.6 \mathrm{~Hz}, 2 \mathrm{H}), 6.85(\mathrm{t}$, $J=7.2 \mathrm{~Hz}, 2 \mathrm{H}), 6.76(\mathrm{t}, J=7.6 \mathrm{~Hz}, 2 \mathrm{H}), 6.46(\mathrm{~d}, J=7.6$ $\mathrm{Hz}, 2 \mathrm{H}), 6.32(\mathrm{~s}, 2 \mathrm{H}), 6.00(\mathrm{t}, J=2.4 \mathrm{~Hz}, 2 \mathrm{H}), 5.63(\mathrm{~s}, 2 \mathrm{H})$, $3.54(\mathrm{~s}, 6 \mathrm{H}), 3.36(\mathrm{~s}, 6 \mathrm{H}) ;{ }^{13} \mathrm{C} \mathrm{NMR}\left(\mathrm{CDCl}_{3}\right) \delta: 200.3$, $159.8,159.3,146.1,142.3,141.3,140.2,135.0,132.8$, $131.7,130.1,129.1,127.3,127.3,126.0,125.8,124.4$, 111.8, 108.3, 99.3, 55.4, 55.3; HRMS (MALDI-TOF) calcd for $\mathrm{C}_{47} \mathrm{H}_{36} \mathrm{O}_{5} 680.2557$, found 680.2563 .

1,4-Bis(3,5-dihexoxyphenyl)-2,3-diphenyl-tribenzo$[a, c, e]$ cycloheptatriene-9-one (6b): To a suspension of $\mathbf{6 a}$ $(1.0 \mathrm{~g}, 1.5 \mathrm{mmol})$ in $120 \mathrm{~mL}$ of anhydrous $\mathrm{CH}_{2} \mathrm{Cl}_{2}$ was added a solution of $\mathrm{BBr}_{3}\left(30.0 \mathrm{~mL}, 1 \mathrm{~mol} / \mathrm{L}\right.$ in $\mathrm{CH}_{2} \mathrm{Cl}_{2}, 30$ mmol, 20 equiv.) at $0{ }^{\circ} \mathrm{C}$ under atmosphere of nitrogen. The reaction mixture was warmed to room temperature and heated to reflux for $4 \mathrm{~h}$, and then was cooled with ice bath and quenched with $\mathrm{H}_{2} \mathrm{O}$. The mixture was extracted with diethyl ether, washed with water and brine, dried with anhydrous $\mathrm{MgSO}_{4}$, and concentrated under reduced pressure. The resulting tetraol was used in the next step without further purification.

To a suspension of the crude tetraol and $\mathrm{K}_{2} \mathrm{CO}_{3}(4.1 \mathrm{~g}$, 30 mmol, 20 equiv.) in $15 \mathrm{~mL}$ of $\mathrm{DMF}$ was added 1-bromohexane (4.2 mL, $30 \mathrm{mmol}, 20$ equiv.) under atmosphere of nitrogen. The reaction mixture was heated at $80{ }^{\circ} \mathrm{C}$ overnight, cooled to room temperature, and then 
quenched with water. The resulting mixture was extracted with diethyl ether, washed with water and brine, dried with anhydrous $\mathrm{MgSO}_{4}$. The resulting solution was concentrated under reduced pressure and the crude product was purified by column chromatography on silica gel with hexane/ $\mathrm{CH}_{2} \mathrm{Cl}_{2}(V: V=1: 1 \sim 1: 2)$ as eluent to afford 1.04 $\mathrm{g}(1.08 \mathrm{mmol})$ of $\mathbf{6 b}$ as white solid in a yield of $72 \%$. m.p. $109 \sim 112{ }^{\circ} \mathrm{C} ;{ }^{1} \mathrm{H}$ NMR $\left(\mathrm{CDCl}_{3}\right) \delta: 7.42(\mathrm{~d}, J=7.6 \mathrm{~Hz}$, 2H), $7.36(\mathrm{~d}, J=7.6 \mathrm{~Hz}, 2 \mathrm{H}), 7.14 \sim 7.11(\mathrm{~m}, 4 \mathrm{H}), 7.02(\mathrm{t}$, $J=7.6 \mathrm{~Hz}, 2 \mathrm{H}), 6.95(\mathrm{t}, J=8.4 \mathrm{~Hz}, 2 \mathrm{H}), 6.81(\mathrm{t}, J=7.2$ $\mathrm{Hz}, 2 \mathrm{H}), 6.75$ (t, $J=7.6 \mathrm{~Hz}, 2 \mathrm{H}), 6.45$ (d, $J=7.6 \mathrm{~Hz}, 2 \mathrm{H})$, $6.30(\mathrm{~s}, 2 \mathrm{H}), 6.00(\mathrm{t}, J=2.4 \mathrm{~Hz}, 2 \mathrm{H}), 5.61(\mathrm{~s}, 2 \mathrm{H}), 3.74 \sim$ $3.70(\mathrm{~m}, 2 \mathrm{H}), 3.61 \sim 3.55(\mathrm{~m}, 4 \mathrm{H}), 3.37 \sim 3.33(\mathrm{~m}, 2 \mathrm{H})$, $1.62 \sim 1.54(\mathrm{~m}, 4 \mathrm{H}), 1.52 \sim 1.51(\mathrm{~m}, 4 \mathrm{H}), 1.34 \sim 1.30(\mathrm{~m}$, $24 \mathrm{H}), 0.93 \sim 0.90(\mathrm{~m}, 12 \mathrm{H}) ;{ }^{13} \mathrm{C}$ NMR $\left(\mathrm{CDCl}_{3}\right) \delta: 200.4$, $159.3,158.8,146.1,142.6,142.1,141.4,140.3,135.4$, $135.1,132.8,131.8,130.2,129.0,127.3,127.2,126.0$, $125.7,124.3,112.6,109.3,100.8,68.3,68.1,31.7,29.2$, 29.0, 22.8, 14.2; HRMS (MALDI-TOF) calcd for $\mathrm{C}_{67} \mathrm{H}_{76} \mathrm{O}_{5}$ 960.5687 , found 960.5681 .

7: To a solution of $\mathbf{6 b}(777 \mathrm{mg}, 0.81 \mathrm{mmol})$ and 2,3-dichloro-5,6-dicyanobenzoquinone $(1.01 \mathrm{~g}, 4.44 \mathrm{mmol}, 5.5$ equiv.) in $400 \mathrm{~mL}$ of anhydrous $\mathrm{CH}_{2} \mathrm{Cl}_{2}$ was added trifluoromethanesulfonic acid (18 mL, $202 \mathrm{mmol}, 250$ equiv.) under atmosphere of nitrogen. The reaction mixture was stirred at room temperature for $18 \mathrm{~h}$ and then carefully quenched with $10 \% \mathrm{NaHCO}_{3}$ solution. The resulting mixture was extracted with $\mathrm{CH}_{2} \mathrm{Cl}_{2}$. The organic layer was washed with brine, dried with anhydrous $\mathrm{MgSO}_{4}$ and concentrated under reduced pressure. The crude product was purified by column chromatography on silica gel with hexane/ $\mathrm{CH}_{2} \mathrm{Cl}_{2}(V: V=1: 1 \sim 1: 2)$ as eluent and subsequently purified by preparative thin layer chromatography with hexane/ $\mathrm{CH}_{2} \mathrm{Cl}_{2}(V: V=1: 1)$ as eluent to afford 392 $\mathrm{mg}(0.43 \mathrm{mmol})$ of 7 as yellow solid in a yield of $53 \%$. m.p. $194 \sim 196{ }^{\circ} \mathrm{C} ;{ }^{1} \mathrm{H}$ NMR $\left(\mathrm{CDCl}_{3}\right) \delta: 9.71(\mathrm{~d}, J=8.4 \mathrm{~Hz}, 2 \mathrm{H})$, $9.40(\mathrm{~d}, J=8.0 \mathrm{~Hz}, 2 \mathrm{H}), 8.99(\mathrm{~d}, J=8.0 \mathrm{~Hz}, 2 \mathrm{H}), 8.04(\mathrm{t}$, $J=8.0 \mathrm{~Hz}, 2 \mathrm{H}), 7.84(\mathrm{~d}, J=7.2 \mathrm{~Hz}, 2 \mathrm{H}), 7.77(\mathrm{t}, J=8.0 \mathrm{~Hz}$, $2 \mathrm{H}), 7.16(\mathrm{~s}, 2 \mathrm{H}), 4.32 \sim 4.24(\mathrm{~m}, 8 \mathrm{H}), 2.10 \sim 2.03(\mathrm{~m}, 4 \mathrm{H})$, $1.98 \sim 1.91(\mathrm{~m}, 4 \mathrm{H}), 1.67 \sim 1.63(\mathrm{~m}, 8 \mathrm{H}), 1.46 \sim 1.35(\mathrm{~m}$, $16 \mathrm{H}), 0.97 \sim 0.91(\mathrm{~m}, 12 \mathrm{H}) ;{ }^{13} \mathrm{C} \mathrm{NMR}\left(\mathrm{CDCl}_{3}\right) \delta: 199.6$, $156.8,156.2,140.4,130.7,130.5,130.1,129.5,128.9$, $128.1,127.4,126.9,126.6,126.5,124.9,124.9,124.5$, $112.2,111.3,99.3,70.0,69.7,31.7,31.6,29.5,26.2,26.1$, 22.8, 22.7, 14.2, 14.1; HRMS (MALDI-TOF) calcd for $\mathrm{C}_{67} \mathrm{H}_{66} \mathrm{O}_{5}$ 950.4905, found 950.4901.

8: To a solution of $7(392 \mathrm{mg}, 0.41 \mathrm{mmol})$ in $28 \mathrm{~mL}$ of anhydrous $\mathrm{CH}_{2} \mathrm{Cl}_{2}$ was added boron trifluoride diethyl etherate $\left(0.70 \mathrm{~mL}, 5.67 \mathrm{mmol}, 14\right.$ equiv.) at $0{ }^{\circ} \mathrm{C}$ under atmosphere of nitrogen. The reaction mixture was kept stirred at $0{ }^{\circ} \mathrm{C}$ for $10 \mathrm{~min}$. Then, a solution of (trimethylsilyl)diazomethane $(0.3 \mathrm{~mL}, 2.0 \mathrm{~mol} / \mathrm{L}$ in hexane, 0.6 mmol, 1.5 equiv.) was added into the mixture slowly. The resulting mixture was kept stirred at $0{ }^{\circ} \mathrm{C}$ for $2.5 \mathrm{~h}$. The reaction mixture was quenched with water. The resulting mixture was extracted with $\mathrm{CH}_{2} \mathrm{Cl}_{2}$. The organic layer was washed with brine, dried with anhydrous $\mathrm{MgSO}_{4}$ and con- centrated under reduced pressure. The crude product was purified by column chromatography on silica gel with hexane $/ \mathrm{CH}_{2} \mathrm{Cl}_{2}(V: V=1: 1 \sim 1: 2)$ as eluent to afford $318 \mathrm{mg}(0.33 \mathrm{mmol})$ of $\mathbf{8}$ as yellow solid in a yield of $80 \%$. m.p. $258 \sim 262{ }^{\circ} \mathrm{C} ;{ }^{1} \mathrm{H} \mathrm{NMR}\left(\mathrm{CDCl}_{3}\right) \delta: 9.59(\mathrm{~d}, J=8.0 \mathrm{~Hz}$, $1 \mathrm{H}), 9.46(\mathrm{~d}, J=8.0 \mathrm{~Hz}, 1 \mathrm{H}), 9.25(\mathrm{t}, J=8.0 \mathrm{~Hz}, 2 \mathrm{H}), 9.00$ $(\mathrm{d}, J=7.6 \mathrm{~Hz}, 2 \mathrm{H}), 8.34(\mathrm{~d}, J=7.6 \mathrm{~Hz}, 1 \mathrm{H}), 8.08 \sim 8.05$ $(\mathrm{m}, 2 \mathrm{H}), 7.65(\mathrm{t}, J=7.6 \mathrm{~Hz}, 1 \mathrm{H}), 7.47 \sim 7.40(\mathrm{~m}, 2 \mathrm{H}), 7.14$ $(\mathrm{d}, J=6.8 \mathrm{~Hz}, 2 \mathrm{H}), 4.40 \sim 4.20(\mathrm{~m}, 4 \mathrm{H}), 4.18 \sim 4.05(\mathrm{~m}$, 4H), 4.08 (d, $J=11.2 \mathrm{~Hz}, 2 \mathrm{H}), 3.66$ (d, $J=10.8 \mathrm{~Hz}, 2 \mathrm{H})$, $2.12 \sim 1.98(\mathrm{~m}, 8 \mathrm{H}), 1.63 \sim 1.45(\mathrm{~m}, 8 \mathrm{H}), 1.42 \sim 1.25(\mathrm{~m}$, $16 \mathrm{H}), 1.00 \sim 0.92(\mathrm{~m}, 12 \mathrm{H}) ;{ }^{13} \mathrm{C} \mathrm{NMR}\left(\mathrm{CDCl}_{3}\right) \delta: 193.3$, $157.9,156.4,155.9,155.8,136.0,135.1,133.1,132.6$, $131.4,131.3,130.4,130.3,129.8,128.2,128.0,127.9$, $127.8,127.3,127.1,126.9,126.7,126.5,126.3,126.1$, $125.5,125.4,125.2,124.7,124.2,124.1,124.0,123.1$, $112.4,112.1,111.7,108.8,98.9,98.1,70.0,69.8,69.6,69.4$, $48.1,31.8,31.7,31.7,29.5,29.5,29.4,26.2,26.2,26.1$, $22.8,22.7,22.7,22.7,14.2,14.2,14.2$; HRMS (MALDI-TOF) calcd for $\mathrm{C}_{68} \mathrm{H}_{68} \mathrm{O}_{5} 964.5061$, found 964.5070.

9: To a mixture of 8 (40 mg, $0.04 \mathrm{mmol})$, lithium aluminum hydride (39 mg, $1.0 \mathrm{mmol}, 25$ equiv.), and aluminum chloride ( $48 \mathrm{mg}, 0.34 \mathrm{mmol}, 9$ equiv.) was added $5 \mathrm{~mL}$ of anhydrous THF at room temperature under atmosphere of nitrogen. The reaction mixture was kept stirred at room temperature for $16 \mathrm{~h}$. The reaction mixture was quenched with water. The resulting mixture was extracted with $\mathrm{CH}_{2} \mathrm{Cl}_{2}$. The organic layer was washed with brine, dried with anhydrous $\mathrm{MgSO}_{4}$ and concentrated under reduced pressure. The crude product was purified by column chromatography on silica gel with hexane/ $\mathrm{CH}_{2} \mathrm{Cl}_{2}(V: V=$ $3: 1)$ as eluent to afford $27 \mathrm{mg}(0.029 \mathrm{mmol})$ of 9 as yellow solid in a yield of $72 \%$. m.p. $173 \sim 178{ }^{\circ} \mathrm{C} ;{ }^{1} \mathrm{H}$ NMR $\left(\mathrm{CDCl}_{3}\right) \delta: 9.43(\mathrm{~d}, J=8 \mathrm{~Hz}, 2 \mathrm{H}), 9.15(\mathrm{~d}, J=8.0 \mathrm{~Hz}, 2 \mathrm{H})$, 8.99 (d, $J=8.0 \mathrm{~Hz}, 2 \mathrm{H}), 8.05(\mathrm{t}, J=8.0 \mathrm{~Hz}, 2 \mathrm{H}), 7.44$ (t, $J=8.0 \mathrm{~Hz}, 2 \mathrm{H}), 7.29(\mathrm{~d}, J=6.8 \mathrm{~Hz}, 2 \mathrm{H}), 7.03(\mathrm{~s}, 2 \mathrm{H})$, $4.37 \sim 4.15(\mathrm{~m}, 8 \mathrm{H}), 3.24 \sim 3.10(\mathrm{~m}, 4 \mathrm{H}), 2.07 \sim 1.96(\mathrm{~m}$, $8 \mathrm{H}), 1.64 \sim 1.60(\mathrm{~m}, 8 \mathrm{H}), 1.45 \sim 1.38(\mathrm{~m}, 8 \mathrm{H}), 1.26(\mathrm{~s}$, $16 \mathrm{H}), 0.97 \sim 0.87(\mathrm{~m}, 12 \mathrm{H}) ;{ }^{13} \mathrm{C}$ NMR $\left(\mathrm{CDCl}_{3}\right) \delta: 156.3$, $155.2,139.7,132.5,129.5,129.4,129.1,128.7,126.4$, $126.1,126.1,125.9,125.5,124.4,122.8,122.3,120.0$, $119.1,112.1,111.4,98.5,69.8,69.6,37.6,31.8,31.8,29.9$, $29.6,26.2,26.2,22.8,22.7,14.3,14.2,14.2$; HRMS MALDI-TOF calcd for $\mathrm{C}_{68} \mathrm{H}_{70} \mathrm{O}_{4}$ 950.5269, found 950.5273 .

Supporting Information X-ray crystallographic information files for compounds 9 and NMR spectra. The Supporting Information is available free of charge via the Internet at http://siocjournal.cn/.

\section{References}

[1] (a) Narita, A.; Wang, X.-Y.; Feng, X.; Müllen, K. Chem. Soc. Rev. 2015, 44, 6616 .

(b) Segawa, Y.; Ito, H.; Itami, K. Nat. Rev. Mater. 2016, 1, 15002. (c) Rickhaus, M.; Mayor, M.; Juríček, M. Chem. Soc. Rev. 2017, 46, 1643. 
(d) Cruz, C. M.; Castro-Fernández, S.; Maçôas, E.; Millán, A.; Campaña, A. G. Synlett 2019, 30, 997.

[2] Bharat; Bhola, R.; Bally, T.; Valente, A.; Cyrański, M. K.; Dobrzycki, Ł.; Spain, S. M.; Rempała, P.; Chin, M. R.; King, B. T. Angew. Chem., Int. Ed. 2010, 49, 399.

[3] Barth, W. E.; Lawton, R. G. J. Am. Chem. Soc. 1966, 88, 380.

[4] Luo, J.; Xu, X.; Mao, R.; Miao, Q. J. Am. Chem. Soc. 2012, 134, 13796.

[5] (a) Kawasumi, K.; Zhang, Q.; Segawa, Y.; Scott, L. T.; Itami, K. Nat. Chem. 2013, 5, 739.

(b) Márquez, I. R.; Fuentes, N.; Cruz, C. M.; Puente-Muñoz, V.; Sotorrios, L.; Marcos, M. L.; Choquesillo-Lazarte, D.; Biel, B.; Crovetto, L.; Gómez-Bengoa, E.; González, M. T.; Martin, R.; Cuerva, J. M.; Campaña, A. G. Chem. Sci. 2017, 8, 1068.

(c) Fukui, N.; Kim, T.; Kim, D.; Osuka, A. J. Am. Chem. Soc. 2017, $139,9075$.

(d) Gu, X.; Li, H.; Shan, B.; Liu, Z.; Miao, Q. Org. Lett. 2017, 19, 2246.

(e) Oki, K.; Takase, M.; Mori, S.; Shiotari, A.; Sugimoto, Y.; Ohara, K.; Okujima, T.; Uno, H. J. Am. Chem. Soc. 2018, 140, 10430.

(f) Fernández-García, J. M.; Evans, P. J.; Medina Rivero, S.; Fernández, I.; García-Fresnadillo, D.; Perles, J.; Casado, J.; Martín, N. J. Am. Chem. Soc. 2018, 140, 17188.

(g) Farrell, J. M.; Grande, V.; Schmidt, D.; Würthner, F. Angew. Chem. 2019, 131, 16656.

[6] Pun, S. H.; Chan, C. K.; Luo, J.; Liu, Z.; Miao, Q. Angew. Chem., Int. Ed. 2018, $57,1581$.

[7] (a) Feng, C.-N.; Kuo, M.-Y.; Wu, Y.-T. Angew. Chem., Int. Ed. 2013, 52,7791 .

(b) Sakamoto, Y.; Suzuki, T. J. Am. Chem. Soc. 2013, 135, 14074.

(c) Miller, R. W.; Duncan, A. K.; Schneebeli, S. T.; Gray, D. L.; Whalley, A. C. Chem. Eur. J. 2014, 20, 3705.

(d) Chen, F.; Hong, Y. S.; Shimizu, S.; Kim, D.; Tanaka, T.; Osuka, A. Angew. Chem., Int. Ed. 2015, 54, 10639.

(e) Miller, R. W.; Averill, S. E.; Van Wyck, S. J.; Whalley, A. C. J. Org. Chem. 2016, 81, 12001.

(f) Cheung, K. Y.; Chan, C. K.; Liu, Z.; Miao, Q. Angew. Chem., Int. Ed. 2017, 56, 9003.

(g) Pun, S. H.; Wang, Y.; Chu, M.; Chan, C. K.; Li, Y.; Liu, Z.; Miao, Q. J. Am. Chem. Soc. 2019, 141, 9680.

[8] Mackay, A. L.; Terrones, H. Nature 1991, 352, 762.

[9] Kim, K.; Lee, T.; Kwon, Y.; Seo, Y.; Song, J.; Park, J.; Lee, H.; Park, J. Y.; Ihee, H.; Cho, S. J.; Ryoo, R. Nature 2016, 535, 131.

[10] Braun, E.; Lee, Y.; Moosavi, S. M.; Barthel, S.; Mercado, R.; Baburin, I. A.; Proserpio, D. M.; Smit, B. Proc. Natl. Acad. Sci. U. S. A. 2018, $115, \mathrm{E} 8116$.

[11] (a) Pun, S. H.; Miao, Q. Acc. Chem. Res. 2018, 51, 1630.

(b) Márquez, I. R.; Castro-Fernández, S.; Millán, A.; Campaña, A. G. Chem. Commun. 2018, 54, 6705.

(c) Stępień, M.; Majewski, M. A. Angew. Chem., Int. Ed. 2019, 58,
86.

[12] Christoph, H.; Grunenberg, J.; Hopf, H.; Dix, I.; Jones, P. G.; Scholtissek, M.; Maier, G. Chem. Eur. J. 2008, 14, 5604

[13] (a) Wong, H. N. C.; Sondheimer, F. Tetrahedron 1981, 37, 99. (b) Wong, H. N. C. Acc. Chem. Res. 1989, 22, 145.

[14] (a) Müller, M.; Iyer, V. S.; Kübel, C.; Enkelmann, V.; Müllen, K. Angew. Chem., Int. Ed. Engl. 1997, 36, 1607.

(b) Nobusue, S.; Fujita, K.; Tobe, Y. Org. Lett. 2017, 19, 3227.

(c) Tamoto, A.; Aratani, N.; Yamada, H. Chem. Eur. J. 2017, 23, 16388 .

[15] Cheung, K. Y.; Xu, X.; Miao, Q. J. Am. Chem. Soc. 2015, 137, 3910.

[16] Resendiz, M. J. E.; Garcia-Garibay, M. A. Org. Lett. 2005, 7, 371.

[17] (a) Grzybowski, M.; Skonieczny, K.; Butenschön, H.; Gryko, D. T. Angew. Chem. Int. Ed. 2013, 52, 9900.

(b) Grzybowski, M.; Sadowski, B.; Butenschön, H.; Gryko, D. Angew. Chem., Int. Ed. 2019, 59, 2998.

[18] (a) Scholl, R.; Mansfeld, J. Ber. Dtsch. Chem. Ges. 1910, 43, 1734. (b) Scholl, R.; Seer, C.; Weitzenböck, R. Ber. Dtsch. Chem. Ges. 1910, 43, 2202.

[19] Zhai, L.; Shukla, R.; Rathore, R. Org. Lett. 2009, 11, 3474.

[20] (a) Plunkett, K. N.; Godula, K.; Nuckolls, C.; Tremblay, N.; Whalley, A. C.; Xiao, S. Org. Lett. 2009, 11, 2225.

(b) Zhai, L.; Shukla, R.; Wadumethrige, S. H.; Rathore, R. J. Org. Chem. 2010, 75, 4748.

(c) Ip, H.-W.; Ng, C.-F.; Chow, H.-F.; Kuck, D. J. Am. Chem. Soc. 2016, 138, 13778.

[21] (a) Hennig, R.; Metz, P. Angew. Chem. Int. Ed. 2009, 48, 1157. (b) Sakai, T.; Ito, S.; Furuta, H.; Kawahara, Y.; Mori, Y. Org. Lett. 2012, 14, 4564.

[22] (a) Chaffins, S.; Brettreich, M.; Wudl, F. Synthesis 2002, 9, 1191. (b) Sletten, E. M.; Nakamura, H.; Jewett, J. C.; Bertozzi, C. R. J. Am. Chem. Soc. 2010, 132, 11799.

[23] King, B. T.; Kroulik, J.; Robertson, C. R.; Rempala, P.; Hilton, C. L.; Korinek, J. D.; Gortari, L. M. J. Org. Chem. 2007, 72, 2279.

[24] CCDC2003773 contains the crystallographic data for $\mathbf{9}$. These data can be obtained free of charge from The Cambridge Crystallographic Data Centre.

[25] Anslyn, E. V.; Dougherty, D. A. Modern Physical Organic Chemistry, University Science Books, Sausalito, 2004, Chapter 1, p. 22.

[26] The commonly used formal potential of the redox couple of ferrocenium/ferrocene $\left(\mathrm{F}_{\mathrm{c}}^{+} / \mathrm{F}_{\mathrm{c}}\right)$ in the Fermi scale is $-5.1 \mathrm{eV}$, which is calculated on the basis of an approximation neglecting solvent effects using a work function of $4.46 \mathrm{eV}$ for the normal hydrogen electrode (NHE) and an electrochemical potential of $0.64 \mathrm{~V}$ for $\left(\mathrm{F}_{\mathrm{c}}^{+} / \mathrm{F}_{\mathrm{c}}\right)$ versus NHE. See: Cardona, C. M.; Li, W.; Kaifer, A. E.; Stockdale, D.; Bazan, G. C. Adv. Mater. 2011, 23, 2367.

[27] (a) Wu, J.; Pisula, W.; Müllen, K. Chem. Rev. 2007, 107, 718. (b) Zhi, L.; Müllen, K. J. Mater. Chem. 2008, 18, 1472. 